\title{
Protection of Refugee Children in India
}

\author{
V. VIJAYAKUMAR
}

\section{Abstract}

This note is an attempt to illustrate the role played by the Indian judiciary in protecting refugee children and their interests in the context of India not being a party to the Refugee Convention or its Protocol. Along with this, the efforts taken by the Supreme Court of India in bridging the gap between India's international obligations and domestic laws, both treaty-based and customary, are mentioned briefly. In doing so, the lack of focused discussion of article 22 of the Convention on the Rights of the Child in protecting unaccompanied and separated children and their interests is also mentioned. The article calls for a more meaningful discussion of these issues in the future.

\section{Résumé}

Cette note tente d'illustrer le rôle joué par l'appareil judiciaire indien pour la protection des enfants réfugiés et de leurs intérêts, avec comme contexte, le fait que l'Inde n'est pas signataire de la Convention sur les réfugiés ou de son Protocole. Par la même occasion, une brève mention est faite des efforts déployés par la Cour suprême de l'Inde pour combler le fossé séparant les obligations internationales de l'Inde et les lois domestiques, à la fois celles fondées sur des traités que celles découlant du droit coutumier. Ce faisant, référence est aussi faite à l'absence de discussions sérieuses dans l'article 22 de la Convention relative aux droits de l'enfant de la protection des enfants non-accompagnés et séparés et de leurs intérêts. L'article réclame des discussions plus sérieuses sur ces sujets à l'avenir.

Though India is not a party to the Convention on the Status of Refugees, 1951, or its Protocol, 1967, India has acceded to a number of international human rights instruments. Yet there is a gap between those international obligations undertaken and in realizing them through the domestic legal framework for effective implementation. Under such circumstances, the Indian judiciary has been play- ing a very important role in bridging the gap through their decisions from time to time. The nature and extent of the international obligations, their applicability, and the nature of reservation as well as the absence of domestic legislation have been discussed by the courts, in the context of constitutional rights and human rights jurisprudence. The primary objective of this short note is to identity some important decisions that seek to protect the rights and interests of refugee children. A few other important decisions of the Supreme Court as well as the High Courts in India are also discussed with a view to assessing the overall effect of those decisions in upholding human rights values in India. The importance of article 22 and other provisions of the Convention on the Rights of the Child in upholding human rights values in India will also be highlighted.
A t the outset, mention must be made of Digvijay Mote v. Government of India and others, ${ }^{1}$ in which 1 a public interest petition was moved before the High Court of Karnataka. It was moved by an individual who acted on the basis of certain reports published in the newspaper as well as his personal visit to a school estab- lished exclusively for accommodating the refugee chil- dren from Sri Lanka. This school was established by an NGO, the Bright Education Society, registered in the state of Tamil Nadu (a province in India), in Bangalore, the capital city of the neighbouring state of Karnataka. This school, conceived as a boarding school, houses two hun- dred and fifty to three hundred refugee children from Sri Lanka exclusively. A majority of them were orphaned or have one of the parents living in the refugee camps in Tamil Nadu and not in a position to take care of the child. The school is administered from funds collected from various donors, individuals as well as organizations. The state of Karnataka also extended its helping hand in 
providing necessary supplies through its Ministry of Women and Social Welfare. However, when the government of Karnataka decided to stop its humanitarian assistance and the school found itself in a difficult situation, the public interest petition was moved before the High Court. Though rejected in the first instance, on appeal before the same High Court, notices were served to all the respondents including the government of Karnataka. On receipt of the notice from the court, the Chief Secretary of the state convened a meeting of all concerned and decided to continue with the humanitarian assistance to the Sri Lankan refugee school and the same was communicated to the court. The petition was disposed of accordingly. However, the school continues to run into financial difficulties frequently. In the recent past, as it could not pay the arrears for the supply of electricity, the state-owned electricity board disconnected the supply. Due to this, the boarding school had to face all sorts of inconveniences. Once again the same High Court was petitioned to restore the power supply. The High Court gave specific directions to the Karnataka State Electricity Board to resume the supply of electricity and accept the payment of arrears in instalments from the school. ${ }^{2}$

In Khy Htoon v. State of Manipur, ${ }^{3}$ the High Court of Guahati went to the extent of staying the deportation order issued against eight Burmese, including children from the age of twelve. Apart from staying the deportation order, the court even went to the extent of releasing them from Manipur central jail on personal bond, as they might not get any surety to come forward, considering their country of origin. The court went one step further and held that these refugees should be permitted to go to New Delhi to seek refugee status from the Office of the United Nations High Commissioner for Refugees. Similar orders were also issued by the Supreme Court of India in Dr. Malavika Karlekar v. Union of India. ${ }^{4}$

In Narendra Bahadur v. State of Uttar Pradesh,${ }^{5}$ the Supreme Court of India held that the courts should be averse to striking down a notification issued by the government for acquisition of land on fanciful grounds based on hyper-technicality. In this case, the notification issued under section 7(1) of the Uttar Pradesh Land Acquisition (Rehabilitation of Refugees) Act, 1948, was assailed by stating that the land acquired was for displaced persons and not for refugees. The Supreme Court held that "what is needed is substantial compliance with law and the notification satisfies that requirement." Thus, the distinction between "refugees" and "displaced persons" in international law has been diluted in the context of the partition of India into two dominions in 1947 as well as in domestic legislation. This approach of the court could also be seen in Collector of 24 Parganas v. Lalith Mohan Mullick, ${ }^{6}$ in which the Supreme Court has also very clearly established the objectives of concepts such as "rehabilitation" and "public purpose" relating to displaced persons. In this case, a notification issued under section 4 of the West Bengal Land Development and Planning Act for settlement and rehabilitation of displaced persons was issued. Subsequently, a decision was taken by the Department of Refugee Relief and Rehabilitation, Government of West Bengal, to allot the acquired land to a society for the establishment of a hospital for crippled children. The Supreme Court observed that:

[P] utting up of a hospital for crippled children is a public purpose connected with the rehabilitation of displaced persons. The original object of acquisition proceedings is generally termed as "resettlement of refugees" which would mean their rehabilitation. By rehabilitation what is meant is not to provide shelter alone. The real purpose of rehabilitation can be achieved only if those who are sought to be rehabilitated are provided with shelter, food and other necessary amenities of life. To provide a hospital for the disabled and for the crippled children of such displaced persons squarely comes within the concept of the idea of "rehabilitation" and consequently of settlement of refugees [emphasis added].

Thus, the construction of a hospital for refugee children was held valid under the concept of "public purpose" on the basis of which even private property could be acquisitioned or requisitioned. In this case, there was acquisition of private property for the construction of a hospital for refugee children.

In National Human Rights Commission v. State of Arunachal Pradesh, ${ }^{7}$ the Supreme Court of India has very clearly established the rights of Chakma refugee children born in the state of Arunachal Pradesh for citizenship. A large number of children were born in India and were entitled to Indian citizenship by birth under section 3 of the Citizenship Act, 1955, prior to the amendment made to it in 1987 requiring one of the parents to be an Indian citizen. However, they also sought to be registered as citizens under section 5 of the same act. In this case, the Court observed that:

[B]y virtue of their long and prolonged stay in the state, the Chakmas who migrated to, and those born in the state, seek citizenship under the Constitution read with section 5 of the Act (Citizenship Act, 1955). By refusing to forward the applications of the Chakmas to the Central Government, the Deputy Collector is failing in his duty and is also preventing the Central Government from performing its duty under the Act and the Rules.

In this regard, the Court went further and observed that: 
[W] are a country governed by the Rule of Law. Our Constitution confers certain rights on citizens. Every person is entitled to equality before the law and the equal protection of the laws. Besides, by refusing to forward their applications, the Chakmas are denied rights, constitutional and statutory, to be considered for being registered as citizens of India [emphasis added].

Apart from these decisions addressing the rights and interests of refugee children, the Supreme Court of India has time and again reiterated India's obligations under contemporary international law based both on the provisions of the Constitution and on the international instruments to which India is a party. In M.C.Mehta v. State of Tamil Nadu, ${ }^{8}$ the Supreme Court gave a set of directions for the abolition of child labour in Sivakasi Match Industries. Reiterating the same, the Supreme Court also referred to articles 3, 27(1), 31(1) and 36 of the Convention on the Rights of the Child in Bandua Mukti Morcha v. Union of India. ${ }^{9}$ The Court held that primary education of children, in particular, children from poor, weaker sections, Dalits and Tribes and minorities, is mandatory. The Court also observed that the ban on employment of children must begin with the most hazardous and intolerable activities like slavery, bonded labour, trafficking, prostitution, pornography, dangerous forms of labour, and the like.

Apart from the decisions mentioned above, the following decisions would indicate the role played by the courts in bridging the gap between international obligations undertaken by India in protecting human rights and in realizing them. To mention a few, the Supreme Court in Gramophone Company of India Limited v. Birednra Pandey, ${ }^{10}$ held that

there can be no question that nations must march with the international community and the municipal law must respect rules of international law just as nations respect international conventions. The comity of nations requires that rules of international law may be accommodated in the municipal law even without express legislative sanction provided they do not run into conflict with Acts of Parliament.

In People's Union for Civil Liberties v. Union of India, ${ }^{11}$ the Court held that "the provisions of the Covenant which elucidate and go to effectuate the fundamental rights guaranteed by our Constitution can certainly be relied upon by the courts as facets of those fundamental rights and hence enforceable as such." In People's Union for Civil Liberties v. Union of India, ${ }^{12}$ the Supreme Court went one step further and held that "the customary principle of international law, if there is nothing against it in the domestic sphere, would be part of the domestic law of the land." The court also observed that "international law is now more focused on individuals than ever before" (emphasis added). In Nilabati Behra v. State of Orissa, ${ }^{13}$ the Court went to the extent of overriding the reservation India had on the International Covenant on Civil and Political Rights and held that individuals are entitled to compensation even in the absence of a statutory law. In another case, Vishaka v. State of Rajasthan, ${ }^{14}$ the Supreme Court very effectively brought the international obligations India has undertaken to the protection of the rights of women and put into place a set of guidelines regarding sexual harassment in workplaces in the absence of any specific law.

In Khudiram Chakma v. State of Arunachal Pradesh, ${ }^{15}$ the Supreme Court of India referred approvingly to the Universal Declaration of Human Rights in relation to refugees. The Court observed:

Article 14 of the Universal Declaration of Human Rights, which speaks of the right to enjoy asylum, has to be interpreted in the light of the instrument as a whole, and must be taken to mean something. It implies that although an asylum seeker has no right to be granted admission to a foreign state, equally a state that had granted him asylum must not later return him to the country he came from. Moreover, the article carries considerable moral authority and embodies the legal prerequisite of regional declarations and instruments.

Again, the Supreme Court in C. Masilamani Mudaliar v. Idol of Sri Swaminathaswami Swaminathaswami Thirukoil ${ }^{16}$ referred to articles 1, 2(b), 3, 13,14,15(2) of the Convention on the Elimination of All forms of Discrimination Against Women (CEDAW) to protect the rights of women. In doing so, the Court observed that:

Article 5(a) of CEDAW to which the Government of India expressed reservation, does not stand in its way and in fact Article 2(f) denudes its effect and enjoins to implement Article (2(f) read with its obligation undertaken under Articles 3,14 and 15 of the Convention vis-à-vis Articles 1,3,6 and 8 of the Convention of Right to Development. These Conventions add urgency and teeth for immediate implementation.

The Court went on to observe that:

[L]aw is an instrument of social change as well as the defender for social change. Article 2(e) of the CEDAW enjoins the Supreme Court to breathe life into the dry bones of the Constitution [emphasis added].

In Madhu Kishwar v. State of Bihar, ${ }^{17}$ the Supreme Court made elaborate reference to CEDAW as well in protecting the rights of women. Referring to the Univer- 
sal Declaration of Human Rights as the "Moral Code of Conduct," the Court read those principles into the domestic jurisprudence in awarding compensation to a foreign national, a woman from Bangladesh. ${ }^{18}$ There are many such decisions of the Supreme Court of India that seek to protect the rights of citizens as well as others seeking to implement the international obligations undertaken by India directly or imposed on her by the customary principles of international law.

In spite of all these decisions, it is interesting to note that no specific reference has been made by any party to a dispute, or by the courts about the international obligations India has undertaken under article 22 of the Convention on the Rights of the Child. ${ }^{19}$ A much closer analysis in this regard would reveal that many other provisions of the Convention on the Rights of the Child have also been ignored. Provisions like article 2 on non-discrimination, article $7(2)$ on registration of birth, and articles 20, 26, 28, 29, 31, 35, and 39 have not been taken into consideration in dealing with one or more refugee groups in India. Proper education and training of government officials, police, custodial institutions, NGOs, and para-military forces along with inclusion of human rights curriculum (with a focus on children's rights) would go a long way to ensuring effective implementation of the Convention on the Rights of the Child in the South Asian region.

\section{Notes}

1. W.A.No 354/1994, Karnataka High Court.

2. Times of India, 3 February 1999.

3. W.P. No. 515/1990, Gauhati High Court.

4. W.P. (Criminal) No. 583/92, Supreme Court of India.

5. (1977) 1 SCC 216.

6. (1986) 2 SCC 138.

7. (1996) 1 SCC 742.

8. (1996) 6 SCC 756.

9. (1997) 10 SCC 549.

10. AIR 1984 SC 677.

11. (1997) 3 SCC 433.

12. (1997) 3 SCC 301.

13. AIR 1993 SC 1960.

14. (1997) 6 SCC 241.

15. (1994) Supp (1) SCC 615.

16. (1996) 8 SCC 525.

17. (1996) 5 SCC 125.

18. Chairman, Railway Board v. Chandrima Das, (2000) 2 SCC 465.

19. Ktaer Abbas Habib Al Qutaifi v. Union of India, 1998 (2) G.L.H. 1005. The Indian government has also reported in its first Country Report to the UN Committee that more than seventy-five thousand children born in India (state of Tamil Nadu) to Sri Lankan refugees have not been registered. See the Country Report, Government of India, February 1997, p. 67.
Dr. V. Vijayakumar, a visiting scholar at the Centre for Refugee Studies during 2000, is also the Centre's international liaison coordinator for Asia. He is a professor of law at the National Law School of India University, Bangalore, India, and administered the UNHCR Chair on Refugee Law until March 2001.

(C) V. Vijayakumar, 2002. This open-access work is licensed under a Creative Commons Attribution-NonCommercial 4.0 International License, which permits use, reproduction and distribution in any medium for non-commercial purposes, provided the original author(s) are credited and the original publication in Refuge: Canada's Journal on Refugees is cited. 